\title{
Merajut Kerukunan Bersama Pemerintah Desa Sri Tanjung, FKUB, Dan Tokoh Masyarakat Kerukunan
}

\author{
Ronald Sianipar $^{1 *}$, Mangiring Tua Togatorop ${ }^{2}$, Erwin B. Joya ${ }^{3}$, Adis Klara Yunita ${ }^{4}$, Messy \\ Causa Primay $^{5}$, Fredy Simanjuntak ${ }^{6}$, Alfons R. Tampenawas ${ }^{7}$ \\ 1,2, 3, 4, 5, 6 Prodi Teologi, STT Real Batam \\ ${ }^{7}$ Prodi Teologi, STT Yerusalem Baru, Manado \\ *sianiparamos@gmail.com
}

\begin{abstract}
This study aims to find out how the Religious Harmony Forum, the Sri Tanjung Village Head and community leaders in the Anambas Islands Regency carry out their roles as stipulated in the Joint Regulation of the Minister of Home Affairs and the Minister of Religion No. 9 and No. 8 of 2006. Research This is a qualitative research using descriptive analysis. The success of harmony and tolerance is largely determined by the role of the Government, Religious Harmony Forum (FKUB) administrators and community leaders as a management team that transmits policy information after it has been formulated at the Central level to the District. This structured accountability is based on the level of bureaucratic compliance with the bureaucracy above it or the level of the bureaucracy as formulated, the existence of a smooth routine and the absence of problems; and implementation and desired impact (benefits) of all existing and targeted programs. So that the policy implementation process as an effort to provide information or messages from higher institutions to lower institutions is measured for its performance success.

Keywords:Harmony, tolerance, Village Government, FKUB, Community Leaders
\end{abstract}

\begin{abstract}
Abstrak
Penelitian ini bertujuan untuk mengetahui bagaimana Forum Kerukunan Umat Beragama, Kepala Desa sri tanjung dan tokoh masyarakat di Kabuapaten Kepulauan Anambas dalam melaksanakan perannya sebagaimana dengan fungsinya yang ditetapkan dalam Peraturan Bersama Menteri Dalam Negeri dan Menteri Agama No.9 dan No.8 Tahun 2006. Penelitian ini merupakan penelitian kualitatif menggunakan analisis deskriftif. keberhasilan sebuah kerukunan dan tolerasnsi sangat ditentukan oleh peran Pemerintah, pengurus FKUB dan Tokoh Masyarakat sebagai tim manajemen yang meneruskan informasi-informasi kebijakan setelah dirumuskan ditingkat Pusat sampai ke Kabupaten. Pertanggungjawaban terstruktur ini didasarkan pada tingkat kepatuhan birokrasi terhadap birokrasi di atasnya atau tingkatan birokrasi sebagaimana telah dirumuskan, adanya kelancaran rutinitas dan tidak adanya masalah; serta pelaksanaan dan dampak (manfaat) dikehendaki dari semua program yang ada dan terarah. Sehingga proses implementasi kebijakan sebagai upaya pemberian informasi atau pesan dari institusi yang lebih tinggi ke institusi yang lebih rendah diukur keberhasilan kinerjanya.

Kata kunci: Kerukunan, toleransi, Pemerintah Desa, FKUB, Tokoh Masyarakat
\end{abstract}

\section{PENDAHULUAN}

Kabupaten kepulauan Anambas terdiri dari sembilan Kecamatan, dua Kelurahan, lima puluh empat Desa dan salah satunya Desa Sri Tanjung yang telah dinobatkan menjadi desa nomor dua di Propinsi Kepualuan Riau sebagai Desa Sadar Kerukunan. Kerukuan antar umat beragama merupakan haluan yang penting yang harus di jaga dan di budayakan di bangsa Indonesia turun temurun karena didalamnya hidup berbagai macam suku,ras, aliran dan Agama. Untuk itu sikap saling menghargai antar sesama yang baik di perlukan sikap yang bisa menjaga perbedaan-perbedaan tersebut agar kerukunan anttar umat beragama dapat tetap terjaga, sebab perdamaian nasional hanya bisa dicapai kalau masing-masing golongan agama pandai menghormati identitas golongan lain. ${ }^{1}$

Masyarakat Kabupaten Kepulauan Anambas secara khusus di Desa Sri tanjung merupakan masyarakat majemuk yang terdiri dari empat Agama yaitu yang diakui oleh pemerintah Indonesia adalah ( agama Islam, Kristen Protestan, Katolik, Buddha dan Kong Hu Chu ) dan tujuh suku ( suku

\footnotetext{
${ }^{1}$ M. Natsir, Islam Dan Kristen Di Indonesia (Jakarta: Media Dakwah, 1988).209
} 
laut, suku melayu, suku cina, suku batak, suku kupang, suku dayak, suku padang) . Kemajemukan yang ditandai dengan keanekaragaman Agama dan Suku itu mempunyai kecenderungan kuat terhadap identitas agama masing-masing dan berpotensi konflik. Dengan perbedaan tersebut apabila tidak terpelihara dengan baik bisa menimbulkan konflik antar umat beragama yang bertentangan dengan nilai dasar Agama itu sendiri yang mengajarkan kepada kita kedamaian, hidup saling menghormati, dan saling tolong menolong.

Penulis sangat yakin bahwa semua ajaran Agama maupun aliran keprcayaan mengajarkan sikap toleransi yang saling menjaga hak-hak orang lain, sikap untuk menerima perbedaan, mengakui hak orang lain, menghargai eksistensi orang lain. Berdasarkan itu kita harus bisa mengubah penyeragaman menjadi keragaman serta mendukung secara antusias terhadap perbedaan budaya dan keragaman ciptaan Tuhan YME

Didalam ajaran Kristen sangat banyak ayat firman Tuhan di Alkitab yang menekankan supaya saling menghargai hak orang lain salah satu ayatnya adalah yang menekankan untuk mengasihi sesama Umat Manusia, Matius 22:39, Mat 5: 43:48 Dan hukum yang kedua, yang sama dengan itu, ialah: Kasihilah sesamamu manusia seperti dirimu sendiri. Bahkan ajaran Yesus Kristus maju satu langkah dengan ajaran Dunia ini yaitu yang mengajarkan untuk mengasihi musuh, meminta berkat kepada orang yang memusuhi kita serta berdoalah untuk orang menyakiti hatimu.

Demikian juga dalam ajaran Islam mengakui hak-hak agama-agama lain, dan membiarkan para pemeluk Agama lain tersebut untuk menjalankan ajaran agama masing-masing. Di dalam ukwah Wathaniayah yang menekankan persaudaraan satu bangsa dan satu tanah air walaupun tidak satu Agama, Inilah dasar ajaran agama Islam mengenai toleransi ber Agama. Akan tetapi toleransi tidak diartikan sebagai sikap masa bodoh terhadap agamanya. ${ }^{2}$

Dalam ajaran Hindu ajaran toleransi termuat pada tri Hita Karana dimana di dalamnya ada tiga pengertian penyebab kesejahteraan yang bersumber kedapada keharmonisan hubungan antar Manusia dngan Tuhannya, Manusia dengan alam lingkungannya, Manusia dengan sesamanya.

Welas asih didalam ajaran Budha yang sangat kental di pegang teguh para penganutnya, dimana ajaran ini meminta agar menghargai sesamanya bahkan semua mahluk hidup termasuk Hewan, karena ajaran budha mengajarkan umatnya menghargai kehidupan. ${ }^{3}$

Jika semua ajaran Agama megamalkan semua kitabnya dengan baik di dalam praktek kehidupan ehari-hari maka bangsa dan dunia ini akan aman dan sentosa. Kerukunan dan toleransi antar umat bergama kiranya akan menjadi agenda Nasional bahkan internasional yang tak kunjung usai, ini bisa menjadi penekanan dari pemulis karena masa depan suatu bangsa sedikit banyak tergantung pada sejauh mana keharmonisan hubungan antar umat ber Agama. Kegagalan dalam merelalisasikan agenda ini akan mengantarkan suatu bangsa pada trauma terpecah belahnya bangsa. ${ }^{4}$ Karenanya,toleransi merupakan kebutuhan yang tidak bisa ditunda-tunda lagi sembari memberikan penjelasan tentang ajaran-ajaran agama yang menekankan pada toleransi beragama,sehinggga jiwa toleransi beragama dapat dibina di kalangan pemeluk masing-masing agama. ${ }^{5}$

Haji Abdul Malik Karim Amrullah atau yang lebih dikenal dengan sebutan Buya Hamka, bisa menjadi teladan tentang bagaimana cara toleransi beragama yang baik. Tahun 1968, umat Muslim berhari raya Idul Fitri dua kali, yaitu pada 1 Januari dan 21 Desember 1968. Dekatnya tanggal Hari Raya Idul Fitri dengan Natal kemudian menginspirasikan sebagian

\footnotetext{
${ }^{2}$ Adeng Muchtar Ghazali, Pemikiran Islam Kontemporer Suatu Refleksi Keagamaan Yang Dialogis (Bandung: Pustaka Setia, 2005).55-58

${ }^{3}$ Sudarsono, Guru Agama Buddha Dan Penjaga Vihara Gunung Siantan Anambas (2020).

${ }^{4}$ M. Quraish Shihab, Atas Nama Agama: Wacana Agama Dalam Dialog Bebas Konflik (Bandung: Pustaka Hidayah, 1988).133

${ }^{5}$ Ma ${ }^{e e}$ ruf Amin, Melawan Terorisme Dengan Iman (Jakarta: Tim Penanggulangan Terorisme, 2007). 148
} 
kepala jawatan dan menteri untuk mengeluarkan perintah agar perayaan halal bihalal digabungkan dengan Natal menjadi Lebaran-Natal. Sebagian pejabat mengatakan bahwa demi kesaktian Pancasila, Lebaran-Natal ini dapat membantu kita memahami makna toleransi. Hamka menolak dengan keras idetoleransi yang semacam itu. Menurut Hamka, toleransi yang semacam itu adalah toleransi paksaan dan memiliki ciri-ciri yang sesuai dengan pandangan sinkretisme. ${ }^{6}$

Nurcholish Madjid adalah seorang cendekiawan Muslim yang juga banyak mengemukakan gagasan pembaharuan dalam Islam, khususnya tentang gagasan mewujudkan kerukunan umat beragama.Menurutnya nilai keislaman itu tidak hanya dipandang dari sudut internal umat Islam dalam berhubungan umat seagama tetapi bagaimana sikap orang Islam terhadap agama lain yaitu mampukah ia membangun sikap saling bertoleransi dalam beragama. Karena sebenarnya kesempurnaan agama Islam adalah karena agama ini bersifat mengayomi semua agama yang ada dan sikap itulah yang dulu dilakukan oleh para sahabat Nabi kepada umat lain $^{7}$

\section{METODE}

Jenis penelitian ini merupakan penelitian deskriptif kualitatif, dimana penulisannya menguraikan dan menjelaskan penelitian sesuai dengan kondisi sebenarnya yaitu untuk mengetahui peranan Pemerintah, FKUB dan Tokoh Masyarakat dalam membina kerukunan warga Desa Sri Tanjung. Teknik pengumpulan data dilakukan dengan Observasi Sugiyono mengemukakan bahwa teknik observasi merupakan suatu proses yang kompleks dan sulit, yang tersusun dari perbagai proses. ${ }^{8}$ Tempat atau lokasi dalam penelitian ini adalah di Desa Sri Tanjung kecamatan Siantan Kabupaten Kepulauan Anambas. Kegiatan PkM ini dilaksanakan pada tanggal 20 Maret 2020 s/d 20 Mei 2020.

\section{HASIL DAN PEMBAHASAN \\ Gambaran Umum Lokasi Penelitian}

Desa Sritanjung terletak di kecamatan siantan Kabupaten Kepulauan Anambas hasil pemekaran dari Desa Tarempa Barat berdasarkan Peraturan Daerah Kabupaten Kepulauan Anambas No: 14 Tahun 2011 Tentang Pembentukan Desa, dan diresmikan pada tanggal 29 Desember 2011. Desa sri tanjung yang berpenduduk laki-laki 429 orang dan perempuan berjumlah 428 orang dengan jumlah total penduduk 857 jiwa adalah desa relatif cukup maju. Secara ekonomi masyarakat Desa Sri tanjung adalah masyarakat yang hidup dari kelas menengah ke bawah. Hal ini dapat dilihat dari kehidupan keseharian mereka. Kebutuhan pangan, sandang dan papan tergolong cukup bahkan secara kasat mata banyak berdiri rumah-rumah masyarakat desa tersebut yang cukup mewah dan ada juga yang hanya dingding papan maupun triplek gersi. Mayoritas masyarakat Desa Sri Tanjung adalah bermata pencaharian sebagai nelayan, tani, PNS dan wirasawasta. lebih jelas tentang mata pencaharian masyarakat Desa Sri Tanjung dapat dilihat pada table berikut:

\begin{tabular}{|l|l|l|}
\hline No & Pekerjaan & jumlah \\
\hline 1 & Tidak/belum bekerja & 239 \\
\hline 2 & Mengurus Rumah Tanggga & 192 \\
\hline 3 & Pelajar/mahasiswa & 113 \\
\hline 4 & PNS & 28 \\
\hline 5 & TNI & 5 \\
\hline 6 & Wiraswasta & 55 \\
\hline 7 & Karyawan swasta & 54 \\
\hline
\end{tabular}

\footnotetext{
${ }^{6}$ Akmal Syafril, "Hamka Tentang Toleransi Beragama," Rubrik Islamia Republika (Indonesia, 2011).24

${ }^{7}$ Nurcholish Madjid, Dialog Keterbukaan Artikulasi Nilai Islam Dalam Wacana Sosial Politik Kontemporer (Jakarta: Paramadina, 1998).268

${ }^{8}$ Sugiono, Memahami Penelitian Kualitatif (Bandung: CV Alfabeta, 2016).166
} 


\begin{tabular}{|l|l|l|}
\hline 8 & Nelayan & 139 \\
\hline 9 & Tani & 15 \\
\hline 10 & Tenaga honorer & 17 \\
\hline & Jumlah penduduk & 857 jiwa \\
\hline
\end{tabular}

Tabel 1. Data Mata Pencaharian Masyarakat Desa Sri Tanjung

Sumber : Laporan Data Kependudukan Pemerintahan Desa Sri Tanjung

Sebagaimana dijelaskan sebelumnya bahwa Desa Tajau Pecah adalah desa yang beragam pemeluk agama. Keragaman agama tersebut dapat dilihat pada table berikut:

\begin{tabular}{|l|l|l|}
\hline No & Agama & jumlah \\
\hline 1 & Islam & 321 \\
\hline 2 & Kristen & 69 \\
\hline 3 & katolik & 115 \\
\hline 4 & budha & 345 \\
\hline 5 & konghucu & 7 \\
\hline
\end{tabular}

Tabel 2. Data Keragaman Agama Masyarakat Desa Sri Tanjung

Sumber : Laporan Data Kependudukan Pemerintahan Desa Sri Tanjung

\section{Interaksi Antar Pemeluk Agama}

Sebagaimana dikemukakan dalam table di atas, bahwa masyarakat Desa Sri Tanjung adalah desa yang masyarakatnya multi agama dan multi etnis. Sebagai desa yang plural Desa sri Tanjung sangat menarik, karena suasana rukun sangat terlihat dalam kehidupan masyarakat desanya. Suasana rukun tersebut dapat dijelaskanpada keadaan berikut:

Saling mengunjungi ketika diundang resepsi perkawinan.

Menghadiri undangan resepsi perkawinan adalah suatu hal yang lumrah dilakukan oleh warga Desa Sri Tanjung yang berbeda agama, bahkan tidak jarang sebagian mereka yang berbeda agama tersebut saling membantu dalam persiapan dan acara resepsi perkawinannya.

\section{Duduk Bersama}

Duduk bersama "bebuol/becite" Berkumpul bersama pemeluk agama yang berbeda baik dengan cara direncanakan atau tanpa suatu rencana biasa terjadi, misalnya mereka berumpul dalam suatu kegiatan rapat di Balai Desa atau sekedar bertemu di satu warung kopi, sambil minum kopi dan makan tambul luti gendang mereka ngobrol tentang berbagai hal, bertukar informasi dan sebagainya. Berhubung penulis adalah salah satu anggota BPD (Badan Permusyawaratan Desa) Desa sri tanjung yang dilantik pada tanggal 07 Juni 2018 sesuai dengan Keputusan Bupati Kepualuan Anambas nomor 349 tahun 2018 tentang Pemberhentian anggota Badan Permuyawaratan Desa masa keanggotaan tahun 20122018 dan peresmian anggota Badan Permuyawaratan Desa masa keanggotaan tahun 2018-2024 di kecamatan Siantan kabupataen kepulauan Anambas.

\section{Kerja Bakti}

Kerja bakti melibatkan seluruh warga masyarakat desa, ada kegiatan rutin gotong royong yang disebut JUBER ( jumat bersih ) yang di lakukan oleh semua aparat Desa sampai ke RT dan tokoh masyarakat. budaya ini sudah menjadi kegiatan rutin terutama kerja bakti ketika menyambut hari ulang tahun kemerdekaan Republik Indonesia setiap tanggal 17 Agustus. Kerja bakti tersebut meliputi membersihkan dan menghias lingkungan desa. Mereka juga terlibat bersama dalam kepanitiaan dan peserta lomba memperingati hari kemerdekaan. Masyarakat juga terlibat bersama-sama dalam kesibukan mempersiapkan pemilihan kepala desa. inilah upaya dilakukan sebagai implementasi kerja Pemerintah Desa yang terus dibudayakan untuk membangun kebersamaan warganya sehingga tercipta kerukunan antar umat bergama. 


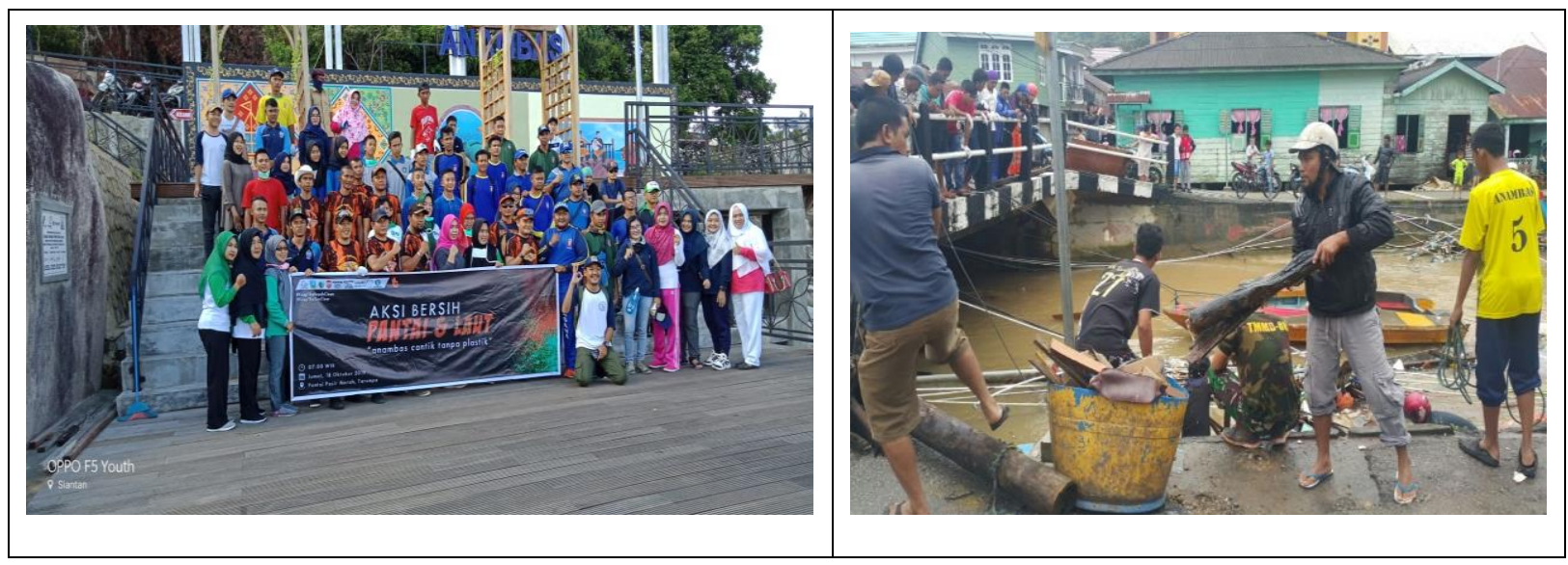

Gambar 1. Interaksi Antar Pemeluk Agama

\section{Kebebasan beribadah sesuai keyakinan agama masing-masing}

Hidup berdampingan dengan pemeluk agama yang berbeda tidak membuat masyarakat Desa Sri Tanjung merasa terganggu untuk mengekspresikan dan mengamalkan ajaran agama mereka. Setiap warga muslim bebas beribadah menurut keyakinan mereka, demikian juga pemeluk Budha, bahkan dalam upacara imlek dengan atraksi barong sai warga muslim ikut menyaksikan upacara tersebut. Untuk pemeluk agama Kristen protestan, sebelum mendapatkan lokasi untuk pendirian Rumah Ibadah. mereka beribadah di Rumah Pastori pendetanya selama enam tahun tanpa ada penolakan maupun gangguan. terbukti setelah mereka mendapatkan lokasi untuk membangun Rumah Ibadah dukungan warga sesuai SKB 2 Menteri untuk pendirian Rumah ibadah cukup dengan hanya tiga hari saja ( 1315 januari 2015 ) sudah mendapatkan izin lingkungan yang disertai tanda tangan dan foto copy KTP, tanda tangan RT/RW dan surat pengantar Kepala Desa yang akan di lanjutkan ke tingkat camat.

Pemeluk Buddha adalah mayoritas pertama setelah islam yang menempati Desa Sri Tanjung, yaitu bejumlah 345 orang. Sebagai penduduk mayoritas pertama, warga Budha sangat memberi warna bagi keadaan desa. Bagi pemeluk Budha membangun Wihara adalah satu keharusan, demikian juga agama yang lain sebagai tempat berkomukinasi dengan Tuhan para pemeluknya. Dan menariknya, siapa saja boleh memasuki area/komplek ibadah mereka untuk sekedar melihat-lihat atau menyaksikan kegiatan ibadah mereka.

\section{Budaya Sebagai Dasar Interaksi}

Bagi setiap warga Negara Indonesia, memeluk agama dan beribadah sesuai dengan keyakinan agama yang dipeluknya adalah hak asasi yang tidak bisa dihalangi oleh apa pun, dan hak asasi ini telah dilindungi oleh perundang-undangan di Indonesia. Beragama daan menjalankan keyakinan agama adalah sesuatu yang komplek, yang berkaitan dengan banyak pihak, terlebih di Indonesia yang notabenemasyarakatnya memeluk agama yang berbeda-beda. Benturan, persinggungan dan konflik sudah terlalu sering terjadi, karena itulah pemerintah membuat program-program untuk penyelesaian konflik untuk daerah-daerah yang berkonflik dan program pencegahan untuk daerah-daerah yang memiliki potensi konflik. Desa Tajau adalah salah satu desa yang menjadi perhatian pemerintah dalam hal pencegahan konfik, sebagai desa yang multi agama dan multi etnis Desa Tajau Pecah termasuk pada kategori desa multikultural. Alfon Taryadi sebagaimana dikutip Andre Ata Ujan mengemukakan ada 5 (lima) jenis multikulturalisme, ${ }^{9}$ yaitu:

1. Multikulturalisme isolasionis; mengacu pada visi masyarakat sebagai tempat kelompokkelompok budaya yang berbeda, menjalani hidup mandiri dan terlibat dalam interaksi minimal sebagai syarat yang niscaya untuk hidup bersama.

${ }^{9}$ Andre Ata Ujan et al., MULTIKULTURALISME (Hidup Bersama Dalam Perbedaan), 3rd ed. (Jakarta: Indeks, 2011). 15 
2. Multikulturalisme akomodatif; mengacu pada visi masyarakat yang bertumpu pada satu budaya dominan, dengan penyesuaian-penyesuaian dan pengaturan yang pas untuk kebutuhan budaya minoritas.

3. Multikulturalisme mandiri; mengacu pada visi masyarakat di mana kelompok-kelompok budaya besar mencari kesetaraan dengan budaya dominan dan bertujuan menempuh hidup mandiri dalam satu kerangkeng politik kolektif yang dapat diterima Multikulturalisme kritis atau interaktif; merujuk pada visi masyarakat sebagai tempat kelompok-kelompok kultural kurang peduli untuk hidup mandiri, dan lebih peduli dalam menciptakan satu budaya kolektif yang mencerminkan dan mengakui perspektif mereka yang berbeda-beda.

4. Multikulturalisme kosmopolitan; mengacu pada visi masyarakat yang berusaha menerobos ikatan-ikatan cultural dan membuka peluang bagi para individu yang kini tidak terikat pada budaya khusus, secara bebas bergiat dalam eksperimen-eksperimen antarkultural dan mengembangkan satu budaya milik mereka sendiri. ${ }^{10}$

Melihat kepada teori 5 (lima) jenis multikulturalisme di atas, maka berdasarkan pengamatan di lapangan, Desa Sri Tanjung termasuk desa multikultur jenis yang pertama yaitu multikulturalisme isolasionis di mana masyarakat adalah sebagai tempat kelompok-kelompok budaya yang berbeda, menjalani hidup mandiri dan terlibat dalam interaksi minimal sebagai syarat yang niscaya untuk hidup bersama. Keadaan ini berada pada tingkat yang paling sederhana dari prosesmultikultural, meskipun demikian sudah merupakan suatu prestasi bagi sebuah desa yang letaknya relatif terpencil dan tingkat pendidikan masyarakatnya yang masih rendah mampu berinteraksi.

Sebagai sebuah desa, Desa Sri Tanjung adalah adalah desa sebagaimana desa-desa yang ada di Indonesia. Koentjaraningrat menjelaskan ada beberapa ciri kehidupan masyarakat pedesaan di Indonesia, ciri-ciri tersebut yaitu:

1. Masyarakat desa adalah masyarkat yang penuh dengan konflik dan persaingan, berdasarkan pengamatan para ahli antropologi mereka justru menemukan banyak pertengkaran di pedesaan. Pertengkaran terutama pada persoalan-persoalan rumah tangga, antar tetangga, sekitar masalah kedudukan dan gengsi, masalah perkawinan, perbedaan kaum tua dan kaum muda, dan perbedaan pria dan wanita, yang terkadang pertengkaran antar pribadi dari persoalan tersebut menjalar menjadi pertengkaran yang lebih besar. ${ }^{11}$

2. Masyarakat desa adalah masyarakat yang bekerja keras. Koentjaraningrat tidak setuju dengan tesis beberapa ahli antropologi bahwa supaya dapat maju orang desa harus dengan positif dengan sesama warganya yang berbeda budaya dan agama didorong untuk bekerja keras, menurutnya orang desa tidak usah ditarik untuk bekerja keras karena mereka sudah bekerja keras, hanya cara-cara dan irama bekerjanya yang harus dirubah dan disesuaikan cara-cara dan irama yang harus dipelihara dengan disiplin, di mana masyarakat desa sering terlalu sibuk di satu waktu tetapi sangat bersantai di waktu yang lain. ${ }^{12}$

3. Sistem tolong-menolong, aktivitas tolong menolong tampak dalam berbagai lapangan kehidupan masyarakat desa di Indonesia, misalnya aktivitas tolong menolong dalam kehidupan rumah tangga dalam menyiapkan dan melaksanakan pesta dan upacara, dalam hal kecelakaan dan kematian. ${ }^{13}$

4. Gotong royong, ciri selanjutnya dari masyarakat pedesaan adalah gotong royong. Gotong royong adalah aktivitas berjasama antara sejumlah besar warga untuk menyelesaikan proyek/pekerjaan tertentu yang dianggap berguna untuk kepentingan umum. Selain itu masih menurut Koentjaraningrat, masyarakat desa juga memiliki jiwa gotong-royong. Gotong royong dengan jiwa gotong royong adalah suatu hal yang berbeda, jiwa gotong royong disebut juga dengan semangat gotong royong dapat diartikan sebagai peranan rela terhadap sesame warga masyarakat, misalnya kebutuhan umum akan dinilai lebih tinggi dari kebutuhan

\footnotetext{
10 Ibid.

${ }^{11}$ Koentjaraningrat, Sosiologi Pedesaan, ed. Sajogyo and Pudjiwati Sajogyo, 5th ed. (Yogyakarta: Gadjah Mada University Press, 1986).34-35

12 Ibid.

13 Ibid.
} 
individu, bekerja bakti untuk umum adalah suatu hal yang terpuji. Lawan dari jiwa gotong royong adalah jiwa individualis, dalam masyarakat individualis kepentingan umum dikalahkan oleh kepentingan-kepentingan individu. ${ }^{14}$

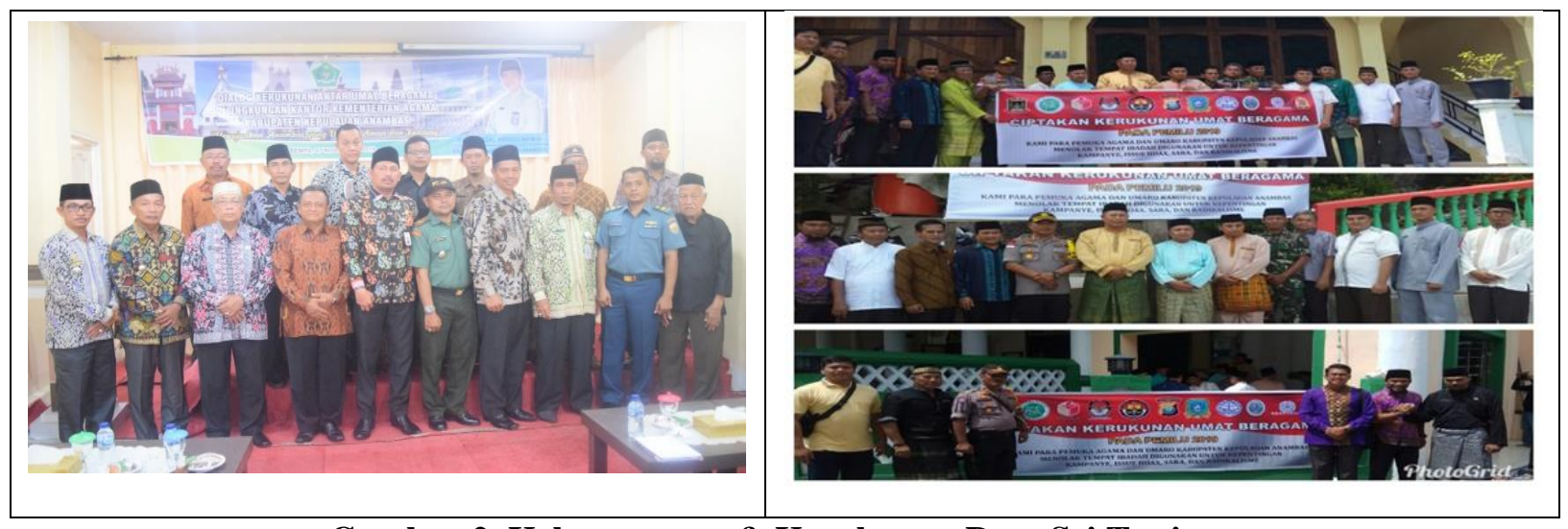

Gambar 2. Kebersamaan \& Kerukunan Desa Sri Tanjung

Berdasarkan Gambar 2 dapat memberi informasi Dengan melihat kepada ciri-ciri masyarakat pedesaan di Indonesia, Desa Sri Tanjung masih sangat kental dengan ciri-ciri tersebut di atas, sehingga ketika muncul pertanyaan mengapa Desa Sri Tanjung yang masyarakatnya relatif masih sederhana dengan tingkat pendidikan yang juga relative masih rendah bisa begitu rukun? Banyak pernyataan bisa disodorkan untuk menjawab pertanyaan tersebut, tetapi penulis berpegang kepada teori antropologi di atas, bahwa Desa Sri Tanjung adalah desa yang masih murni desa "ala"Indosnesia, di mana penduduknya meskipun beragam tetapi masih datang dari berbagai pelosok yang masih merupakan wilayah Indonesia, yaitu dari Nusa Tenggaa Timur ( yaitu suku Kupang dan Flores ), Pulau Kalimantan (Banjar dan Dayak), Pulau Sumatera (Batak Toba, Mandailing, Padang ) dan Pulau Dewata Bali, di mana mereka masih memiliki sikap mental yang relative sama yaitu kultur dan budaya yang khas Indonesia. Keadaan ini memberi kondisi yang kondusif bagi Desa Sri Tanjung karena meskipun mereka datang dari berbagai daerah dan pulau yang berbeda tetapi masih dalam lingkup kultur dan budaya yang sama, yaitu budaya pedesaan yang menjunjung tinggi gotong royong, tolongmenolong dan musyawarah.

\section{Solidaritas Dalam Interaksi}

Sebagai warga, masyarakat Desa Sri Tanjung begitu sadar bahwa mereka hidup dalam satu lingkungan yang saling membutuhkan, sehingga interaksi-interaksi yang terjadi dalam kegiatan gotong royong, musyawarah, kerjabakti dan bertoleransi dalam kepentingan agamaadalah sikap yang muncul secara spontan.

Berbicara tentang hubungan antar pemeluk agama, akan ada 2 (dua) kategori yang akan selalu melekat pada kata hubungan tersebut yaitu hubungan baik atau rukun atau integrasi dan hubungan yang tidak baik atau konflik atau disintegrasi. Desa Sri Tanjung adalah desa yang hubungan antar warganya yang berbeda agama bisa dikategorikan memiliki hubungan yang baik, hal ini sangat jelas terlihat dari interaksi antar pemeluk agama sesama warga desa dalam kehidupan sehari-hari, dan keadaan ini adalah sesuatu yang sangat positif yang harus dicontoh untuk desa-dasa lainnya. Sebagai sebuah desa binaan kerukunan, membina agar masyarakatnya dapat hidup rukun dan dapat bekerjasama antar sesama warga desa yang berbeda agama adalah menjadi tanggungjawab pemerintah, karena itu lah peran Pemerintah Desa, Forum Kerukunan Umat Beragama, Tokoh Masyarakat Desa Sri Tanjung sebagai perpanjangan tangan Pemerintah di Kabupaten Kepulauan

14 Ibid. 
Anambas sangat strategis. Melihat kepada tujuan dibentuknya desa binaan, maka ini memiliki tugas yang luas, tujuan-tujuan tersebut yaitu:

1. Terbentuknya kepengurusan kerukunan di tingkat Desa / Kampung-Memelihara keragaman umat beragama dan ragam suku bangsa Indonesia yang majemuk

2. Mendukung kegiatan masyarakat yang menjadi penghasilan masyarakat desa dimaksud

3. Memaksimalkan fungsi dan peran fasilitas "rembug desa" dan atau "balai Desa" dan atau semacamnya dalam penyelesaian permasalahan dengan jalan kerukunan

4. Adanya prospek percontohan kerukunan dilihat dari potensi spritualitas dan infra struktur desa /kampong dimaksud

5. Akan didapat/muncul mitra kerja FKUB di Kabupaten Kepulauan Anambas yang bersedia dalam mendampingi dalam kegiatan sehari-hari selanjutnya sebagai kontak forum

6. Kelanjutan pembinaan "Desa sadar Kerukunan" ini nantinya dengan bekerja sama dengan pemerintah daerah mendukung adanya Desa sadar kerukunan ini dalam bentuk APBD/ bantuan pendanaan lembaga terkait, sehingga berkesinambungan.

Jika tugas-tugas di atas terlaksana secara maksimal, tentunya kerukunan semakin bisa ditingkatkan, toleransi tidak lagi sebatas pengakuan tetapi sudah pada taraf saling menguntungkan untuk kemajuan ekonomi, politik, budaya pendidikan dan lain-lain. Selain itu bentuk meultikulturalisme sebagaimana diuraikan sebelumnya juga akan bisa ditingkatkan kepada bentuk multikulturalisme kritis atau interaktif, yaitu suatu bentuk multikulturalisme di manamasyarakatnyasebagai tempat kelompok-kelompok kultural kurang peduli untuk hidup mandiri, dan lebih peduli dalam menciptakan satu budaya kolektif yang mencerminkan dan mengakui perspektif mereka yang berbeda-beda.

Keberadaan Forum Kerukuanan Umat Beragama juga sangat diperlukan karena sebuah desa sebagaimana Desa Sri Tanjung yang multicultural, juga memiliki potensi-potensi disintegrasi. Disintegrasi inilah yang penting dicegah jauh-jauh hari sebelumnya. Melihat kepada Desa SriTanjung, hal yang perlu diwaspadai adalah pemukiman Pemeluk agama tertentu mengelompok sendiri. Jusuf Kalla dalam sebuah pernyataannya menjelaskan bahwa "ia tidak memperkenankan pengelompokan domisili dari kelompok yang sama didaerah atau wilayah yang sama secara eksklusif. Jadi tempat tinggal/domisili atau perkampungan sebaiknya mixed, atau campuran dan tidak mengelompok berdasarkan suku (etnis), agama, atau status sosial ekonomi tertentu".

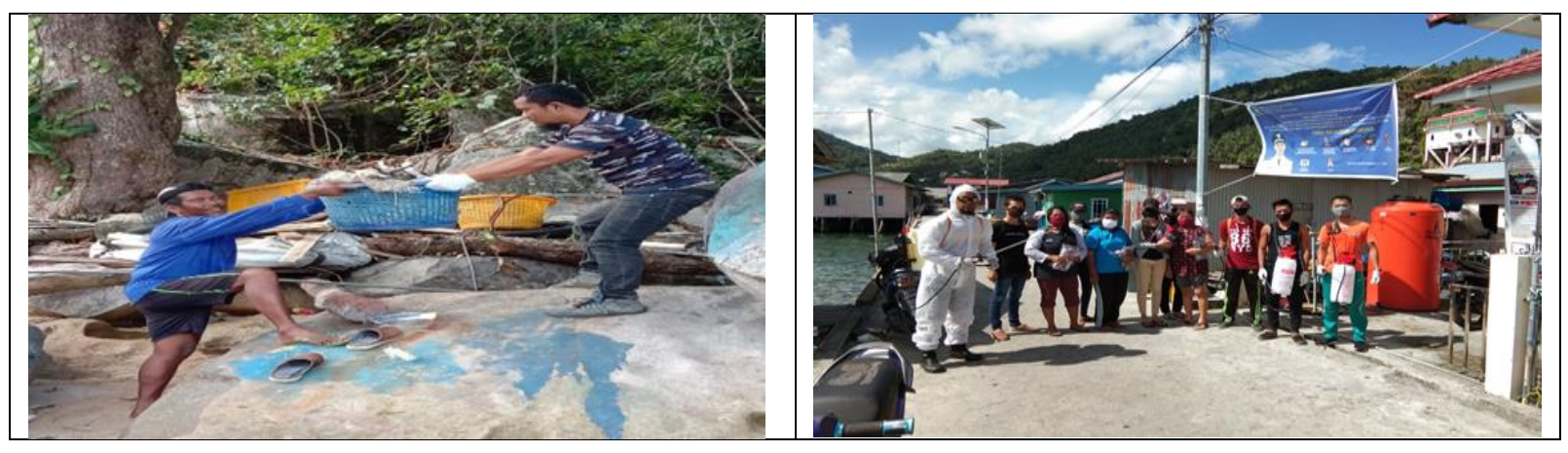

Gambar 3. Gambar Solidaritas \& Interaksi Masyrakat Desa Sri Tanjung

\section{SIMPULAN}

Berdasarkan seluruh pembahsan diatas dapat disimpulkan:1) Sebagai desa yang multi agama dan multi suku bangsa, Desa Sri Tanjung adalah desa multicultural yang isolasionis; di mana masyarakat sebagai tempat kelompok-kelompok budaya yang berbeda, menjalani hidup mandiri dan terlibat dalam interaksi minimal sebagai syarat yang niscaya untuk hidup bersama.Interaksi yang terjadi seperti 
kerjabakti, tolong menolong dan saling bertoleransi adalah diantara ciri-ciri perilaku masyarakat pedesaan yang ada di Indonesia, sehingga dapat dijelaskan bahwa interaksi positif yang terjadi adalah karena factor budaya yang mereka miliki sebagai warga dan masyarakat Indonesia.

, 2) Forum Kerukunan Umat Beragama, Kepala Desa, Tokoh Masyarakat di Kabupaten/wilayah merupakan ujung tombak utama bagi terwujudnya kerukunan umat beragama sebagaimana kerinduan semua daerah. Untuk itu diperlukan langkah konkrit untuk memberdayakan dan memperkuat kehadiran FKUB baik di Kabupaten maupun kecamatan. Penguatan kelembagaan keorganisasian dengan memfungsikan seluruh perangkat FKUB dan pemerintah yang ada sesuai dengan pembagian tugas masing-masing.

\section{SARAN}

1. Peran Pemerintah Desa, Pengurus FKUB dan Tokoh Agama sebagai desa Sadar Kerukunan perlu ditingkatkan, sehingga interaksi yang terjadi lebih meningkat kepada bentuk kerjasama yang membangun.

2. Pihak FKUB Kabupaten Kepulauan Anambas sebagai mitra Pemerintah Desa dan Tokoh Masyarakat sebagai pihak yang membawahi langsung Desa Sadar Kerukunan penting sekali untuk memberikan perhatian dan pengawasan, sehingga kegiatan-kegiatan yang dilakukan lebih terarah dan kerukunan semakin meningkat.

3. Kepada warga masyarakat perlu juga untuk disosialisasikan tentang positif dan negatifnya keadaan desa mereka yang multi suku bangsa, multi pemeluk agama dan sebagainya, sehingga mereka menyadari keadaan mereka yang sesungguhnya.

4. Kegiatan "bebuol/becite" ditingkatkan tidak tebatas hanya pada tokoh masyarakatnya, tetapi juga masyarakat awam.

\section{DAFTAR PUSTAKA}

Amin, Ma"ruf. Melawan Terorisme Dengan Iman. Jakarta: Tim Penanggulangan Terorisme, 2007.

Ghazali, Adeng Muchtar. Pemikiran Islam Kontemporer Suatu Refleksi Keagamaan Yang Dialogis. Bandung: Pustaka Setia, 2005.

Koentjaraningrat. Sosiologi Pedesaan. Edited by Sajogyo and Pudjiwati Sajogyo. 5th ed. Yogyakarta: Gadjah Mada University Press, 1986.

Madjid, Nurcholish. Dialog Keterbukaan Artikulasi Nilai Islam Dalam Wacana Sosial Politik Kontemporer. Jakarta: Paramadina, 1998.

Natsir, M. Islam Dan Kristen Di Indonesia. Jakarta: Media Dakwah, 1988.

Shihab, M. Quraish. Atas Nama Agama: Wacana Agama Dalam Dialog Bebas Konflik. Bandung: Pustaka Hidayah, 1988.

Sudarsono. Guru Agama Buddha Dan Penjaga Vihara Gunung Siantan Anambas (2020). Sugiono. Memahami Penelitian Kualitatif. Bandung: CV Alfabeta, 2016. Syafril, Akmal. "Hamka Tentang Toleransi Beragama." Rubrik Islamia Republika. Indonesia, 2011. Ujan, Andre Ata, Benyamin, Nugroho, Warsito Djoko, and Hendar Putranto.

MULTIKULTURALISME (Hidup Bersama Dalam Perbedaan). 3rd ed. Jakarta: Indeks, 2011. 